\title{
Manipulating Permeability as a Process for Controlling Crime: Balancing Security and Sustainability in Local Contexts.
}

Dr Paul Cozens and Dr Terence Love, Design Out Crime Research Centre (Curtin University of Technology)

\begin{abstract}
In response to the sustainability agenda, planning policy in the UK, USA and Australia has shifted to promote compact, high-density, mixed-used residential developments in walkable and permeable street networks close to public transport (Commonwealth of Australia, 1995; DETR, 1998; American Planning Association, 2007). This is to encourage walking and the use of public transport and to reduce car-use, energy use, pollution, congestion and urban sprawl. However, although permeability is assumed to represent a positive built environment feature which reduces crime by promoting more 'eyes on the street' (Jacobs, 1961), a significant body of research in the field of environmental criminology challenges this assumptions. This paper reviews the theories and evidence associated with permeability and crime.

Pedestrian access ways (PAWs) are often associated with crime and this paper discusses research which was directed at providing practical guidance to local governments on how they could better manage existing PAWs in Western Australia (WA). A morphological analysis of existing PAWs was undertaken which analysed the purposes, roles, functionality, users and dynamics of PAWs in a variety of different settings. In addition to crime (which had commonly be used as an excuse to close PAWs), the research considered issues such as amenity, walkability, equity and sustainability. A suite of five tools for assessing and reducing crime risk were developed, which attempt to balance security and sustainability issues. Contrary to assumptions, most PAWs were not subject to high levels of crime and many were vital to the community. Intriguingly, findings indicated that neighbourhood permeability can potentially be manipulated (via the management, closure or construction of new PAWs) to achieve the desired outcomes of reducing crime and of enhancing walkability, liveability and ultimately, the sustainability and well-being of communities.
\end{abstract}




\section{Introduction}

Over recent years, there has been a growing acceptance that the World's non-renewable resources are being rapidly depleted and that Western cities are increasingly characterised by an over-consumption of resources and increased levels of congestion, pollution, cardependency and obesity. These issues are encompassed under the general theme of sustainable development. An important planning policy response in the UK, USA and Australia has been to promote compact, high-density, mixed-used residential developments in walkable and permeable street networks close to public transport (Commonwealth of Australia, 1995; DETR, 1998; American Planning Association, 2007). The aims of the subsequent planning policies are to reduce car-use, increase the use of public transport, and to promote walking / cycling. These measures are intended to improve human health and ameliorate the impacts of urban sprawl such as pollution, congestion, energy use associated with car-dependency and obesity.

In parallel to these positive planning aspirations, the ubiquitous issues of crime and fear of crime continue to plague our cities and to challenge those with the responsibility for crime prevention. In Britain, Section 17 of the Crime and Disorder Act 1998 places a duty on local authorities to do all that they reasonably can, in order to reduce crime. There is a growing recognition that crime prevention is no longer the sole responsibility of the police, rather, it is a role for all of society, including local governments, communities, urban designers, planners and built environment professionals and security agencies (Schneider and Kitchen, 2007).

Crime and the fear of crime are high profile issues for citizens, communities, police and governments. Reducing crime using planning and design initiatives is a relatively new but increasingly popular trend (Cozens, 2005, Schneider and Kitchen, 2002; 2007). Brantingham and Brantingham (1993) observed how planning decisions shape crime. In its Human Settlements Programme, The United Nations, recommends using Designing Out Crime (DOC) and crime prevention through environmental design (CPTED) to change environments that are conducive to crime as one of the implementation procedures to achieve "Safer Cities"(UN Habitat, 2007).

Internationally, the environmental movement has played a central role in creating increased awareness of the idea of sustainability. Typically, however, crime, the fear of crime and crime reduction has not yet been effectively integrated within the sustainability discourse (Cozens, 2008a). The links between sustainability and crime prevention have been observed by various researchers (e.g. Du Plessis, 1999; Cozens, 2002; Knights et al., 2002; Dewberry, 2003). However, crime prevention has not represented a meaningful focus for the sustainability agenda (Cozens, 2002; Cozens, 2008a). This is despite awareness that 'no city can call itself sustainable if the citizens of that city fear for their personal safety and the safety of their livelihood' and that 'security is an integral part of sustainability, and it is generally essential if people are to achieve their full potential' (Black, 2004, p8; Du Plessis, 1999, p33).

As early as 1977, Herbert (p. 208) noted 'environmentalism might have provided the most logical link to a geography of crime. That it did not do so was in part a function of scale, but more particularly was a function of its view of the natural environment as the habitat of man.' This offers a significant opportunity because the sustainability agenda could be well-placed to engage with crime prevention through environmental design (CPTED) as a form of 'urban environmentalism’ (Cozens, 2002).

Urban planning is central to managing all aspects of sustainability including crime reduction. The world is increasingly urbanised. For example, most of the population in the UK (89\%) is now situated in 'urban' areas (General Household Survey, 1996) and the majority of the world's population are projected to be urbanised by 2050 (UNCHS, 1996). Crime and the fear 
of crime are generally more prevalent in urban areas (Bottoms and Wiles, 1997). This is likely to have profound future implications particularly since urbanisation is linked to a range of sustainability issues such as pollution, congestion and obesity.

Since the 1990s, urban sprawl has been increasingly criticized and rejected as a viable form of urban development largely due to the associations with car-dependency, lack of public transport, a reduction in physical activity and rising levels of obesity. Urban sprawl and the rapid increase in the number of cars and car journeys have undoubtedly contributed towards reducing the relative benefits of living in the suburbs. This has led to a shift towards what has become known as 'permeable' cities. Permeability refers to the extent to which urban forms allow (or restrict) the movement of pedestrian or vehicular traffic in different directions. Southworth and Ben-Joseph argue (2004) that the basic suburban cul-de-sac has now come to symbolize all the problems of suburbia and this has also contributed to the policy shift to more permeable grid-style street configurations. Indeed, in parts of America the cul-de-sac has been banned (Southworth and Ben-Joseph, 2004)._According to Armitage (2007), the origins of the global policy shift towards more permeable residential neighbourhoods can be traced to the Agenda 21 document from the Rio Earth Summit in 1992 (United Nations Conference on Environment and Development). This promoted sustainable development, which in addition to many other broader environmental, social and economic goals, encouraged people to walk and cycle, rather than drive their vehicles, thereby reducing congestion and pollution.

The issue of street permeability has therefore become central to considering how to deliver less crime and more sustainable urban design. There are two distinct perspectives to this topic: the 'encounter' model and the 'enclosure' model.

According to the 'encounter model' (Dovey, 1998), permeable streets are safer since they encourage walking, social interaction and increased levels of 'eyes on the street' (see, also, Jacobs, 1961). From this perspective the presence of strangers (as additional eyes on the street) is regarded as a positive element, whereby they can help to police spaces, while the inhabitants police the strangers.

The proponents of the 'enclosure model' (Dovey, 1998) have argued that limiting permeability by controlling access to strangers means that residents can more readily distinguish strangers and potential criminal behaviour, and thereby reduce opportunities for crime. Derived from Newman's Defensible Space (1973) these ideas have been adopted as an agenda for enclosure, retreat and privatisation (Dovey, 1998) rather than promoting openness and accessibility. However, Schneider and Kitchen (2007, p40) argue it is an oversimplification to suggest that defensible space 'endorses segregated space as inherently safe or that surveillance is its single defining criterion’.

This 'enclosure versus encounter' debate has been raging since the 1970's and the theoretical foundations are largely grounded in the observations of Jacobs (1961) and the research and perspectives of Newman (1973) and Hillier (1973) respectively. For local governments in the UK, for example, it appears the planning policy shift to more permeable street configurations has resulted in confusion, conflict and contradiction (Armitage, 2007), since the crime prevention advice provided by the police (see www.securedbydesign.com) advocates minimal permeability. This tension between the 'enclosure' and 'encounter' debate is clearly an issue in terms of balancing sustainability and security in the quest for vibrant, liveable, safe and sustainable urban spaces and communities.

This paper will explore the 'enclosure versus encounter' debate in more detail after outlining the main points of each position and will present some of the key evidence associated with permeability. The paper will then briefly describe the insights gained from an innovative applied research project into improving the management of pedestrian access ways (PAWs) in 
Western Australia (WA). This PAW research highlighted many of the contradictions inherent within the 'enclosure versus encounter' debate and prompted the researchers to challenge some of the assumptions which underpin each perspective. This PAWs research project is presented as a case study for introducing the concept of manipulating permeability as a process for reducing crime and for potentially balancing security and sustainability issues. The research was funded by the WA Office of Crime Prevention and was conducted in 2007-2008 by Dr Paul Cozens and Dr Terence Love of the Design Out Crime Research Centre, located across Curtin University of Technology and Edith Cowan University (see www.designoutcrime.org). The paper will conclude by drawing together the main issues into recommendations for promoting improved urban sustainability.

\section{The Permeability Debate - 'Permeable is Good': The Encounter Model}

Current planning policy in the UK, America and Australia (including New Urbanism) has identified that cul-de-sac street layouts are car-oriented and pedestrian-hostile, compared to grid layouts. Jane Jacobs’ The Death and Life of Great American Cities (1961) largely reinforces this perspective. She argued against the separate zoning of land-uses since it destroyed the vitality and diversity of the street and the development and maintenance of informal social controls. Jacobs (1961) and later Hillier and Hanson (1984) observed how urban vitality is dependent on highly permeable urban configurations with short blocks and multiple connections. This form of urban structure encourages use by strangers but controls their activities by virtue of the close proximity to the 'eyes on the street' from residents living in adjacent properties. It is proposed from this point of view that permeable grid layouts promote walkability by virtue of their increased levels of accessibility and this walkability potentially promotes a stronger sense of community and higher levels of social interaction, and, therefore, reduced levels of crime and fear of crime.

It is argued that permeable street layouts are preferable to non-permeable varieties for crime prevention by virtue of the increased potential for passers by and strangers to frequent the area and to provide 'eyes on the street' in addition to that provided by the residents. For Jacobs (1961) and Hillier (2004), the presence of strangers can act as a natural policing mechanism. They argued that natural surveillance is not only provided internally by residents, but also externally by all users of space. From this perspective, permeability and increased accessibility to residential streets, works to reinforce natural surveillance and hence should enhance both safety and the perceived safety of residents.

The evidence cited to back up these claims includes Rudlin and Falk (1995); Hillier and Shu (1998) and Shu (2000). However, this evidence is predominantly related to various Space Syntax studies derived from the work of Hillier and Hanson (1984). Several studies have indicated that crime incidents, particularly residential burglary, are concentrated in the more isolated and less accessible streets (Jones and Fanek, (1997); Hillier and Shu, (2000); Shu and Huang, (2003). Space Syntax research concerning the mapping and monitoring of pedestrian movement is also supportive of more permeable layouts, which promote intervisibility. However, more recent work (Hillier, 2004) recognises that it is 'leaking' cul-de-sacs which are associated with crime rather than cul-de-sacs per se. Hillier (2004) also observes that connected grid-style streets can also be vulnerable to crime if they are designed with a system of access by rear alleys.

The definition and measurement of accessibility in the Space Syntax methodology is open to criticism since levels of use are largely estimated rather than actually observed or systematically recorded. Local integration measures may well correlate with estimated numbers of street users, but actual levels of pedestrian footfall on these streets are often assumed rather than measured. An additional assumption lies in that way that Space Syntax 
studies often compare and analyse grid layouts and cul-de-sacs, without distinguishing between 'pure' cul-de-sacs and 'leaking' cul-de-sacs. This oversight is critical, since a 'leaking' cul-desac is one which is linked to other spaces via pedestrian access ways (PAWs) while a 'pure' cul-de-sac is not. A 'leaking' cul-de-sac may well be as accessible and permeable as a grid layout, as least from the perspective of the pedestrian. Consequently, from a crime prevention perspective, findings from Space Syntax studies are largely inconclusive and the complexity of the approach hinders detailed scrutiny and critical inspection.

Crucially, the presence of 'eyes on the street' does not guarantee intervention. Indeed, studies which have investigated bystander apathy have found that as the number of bystanders increase, the likelihood for intervention decreases (Darley and Latane, 1968; Morgan, 1978). The study of bystander behaviour is important to understanding crime and has recently been applied to the field of interpersonal violence (Hart and Miethe, 2008; Barnyard, 2008).

\section{The Permeability Debate - 'Permeable is Bad': The Enclosure Model}

Dovey (1998) observes that the concept of 'enclosure' is as old as the walled city itself and this idea also found in the modern suburban cul-de-sac. Here, it is argued that the community is protected from through-traffic by non-residents. Within this shared space, access to 'strangers' is thereby limited by the lack of access which means they will potentially be noticed and observed more easily by residents.

Newman's idea of Defensible Space (Newman, 1973) underpins modern ideas of crime prevention through environmental design (CPTED). Newman asserted that natural surveillance opportunities provided by the built environment is one of the mechanisms that allow residents to notice non-residents and to potentially act as capable guardians. Residents' sense of 'ownership' or territoriality in a residential area can be supported and defined by the built form such that strangers can be more easily recognized and potentially challenged. In terms of the built form, controlling access to residential neighbourhoods to discourage non-entry by nonresidents is widely considered to be a crime-reducing process. This works in the same way that access control is applied to shopping centres, railway stations, airports and banks, for example, to limit access to certain individuals / groups at certain times. Non-permeable residential areas are therefore regarded as being potentially safer, since non-residents and potential offenders are less likely to routinely drive / walk through such areas and notice criminal opportunities. Furthermore, when and if they do, it is argued that residents will be more likely and able to notice and identify such individuals.

Another way of viewing this is that increased levels of permeability equates to more access for all citizens (including potential offenders) (Ekblom, 1995). Highly permeable, walkable and accessible streets can therefore provide increased opportunities for crime. These opportunities can be exacerbated if such streets are located in low density suburbs, where 'eyes on the street' provided by residents and passers by are likely to be reduced.

Secured By Design (SBD) is a UK initiative developed in 1989 by the Association of Chief Police Officers (ACPO) and supported by the Home Office Crime Prevention Unit whereby new-build housing developments utilise 'defensible space' and CPTED ideas to reduce opportunities for crime. It draws extensively on Newman's Defensible Space and it largely discourages high levels of permeability. This is in direct contrast to current planning policies that encourage permeability as part of the sustainability agenda.

Controversially, a report by Knowles, (2006) entitled Designing Out Crime - The Cost of Policing New Urbanism claimed that policing costs for a 4500 housing development would be three times higher for permeable New Urbanist designs as compared with the non-permeable cul-de-sac layouts promoted by the SBD scheme. This report also asserted that reported crime 
is five times higher in the New Urbanist layouts investigated (Town et al., 2003; Town \& O’Toole, 2005). In surveys, six of the first seven reasons burglars stated for selecting a particular property were related to access routes (Town et al., 2003). SBD largely promotes the use of non-permeable cul-de-sac layouts, and several evaluations (Brown, 1999; Pascoe, 1999; Armitage, 2000) have indicated its effectiveness in reducing crime and the fear of crime (for a review of SBD see Cozens et al., 2004; 2007).

Studies by Newman (1973; 1980, 1996) and others (Poyner, 1983; Coleman, 1985; Poyner and Webb, 1991) have all indicated an association between design features and levels of crime; particularly features that allowed unrestricted pedestrian movement through residential complexes. According to Eck (1997) research has intimated that areas with unregulated access have more crime than areas with street layouts with more restricted access (White, 1990; Beavon et al., 1994). Crucially, there is extensive and compelling research which has been conducted over the last thirty years which consistently indicates that levels of crime are higher in more permeable, accessible, well-used street networks (for a review see Cozens, 2008b). Table 1 lists many of the key studies which indicate that permeability is linked to increased levels of crime.

Table 1 Studies Linking Permeability with Increased Levels of Crime

\begin{tabular}{|l|c|l|c|}
\hline Author(s) & $\begin{array}{c}\text { Date of } \\
\text { Study }\end{array}$ & Author & $\begin{array}{c}\text { Date of } \\
\text { Study }\end{array}$ \\
\hline Brantingham and Brantingham & 1975 & Brantingham et al & 1977 \\
\hline Bevis and Nutter & 1978 & Newman & 1980 \\
\hline Rubenstein et al & 1980 & Newlands & 1983 \\
\hline Brown and Altman & 1983 & Beavon & 1984 \\
\hline Greenberg and Rohe & 1984 & Taylor and Gottfredson & 1987 \\
\hline White & 1990 & Sheard & 1991 \\
\hline Cromwell et al & 1991 & Poyner and Webb & 1991 \\
\hline Matthews & 1992 & Brantingham and Brantingham & 1993 \\
\hline Matthews & 1993 & Atlas and Le Blanc & 1994 \\
\hline Beavon et al & 1994 & Newman & 1995 \\
\hline Popkin et al & $1995 \mathrm{a}$ & Popkin et al & $1995 \mathrm{~b}$ \\
\hline Newman & 1996 & Wagner & 1997 \\
\hline Lasley & 1998 & Mirlees-Black et al & 1998 \\
\hline Rengert and Hakim & 1998 & Pascoe & 1999 \\
\hline Brown & 1999 & Armitage & 2000 \\
\hline Zavoski et al & 1999 & Rengert and Wasilchick & 2000 \\
\hline Brantingham and Brantingham & 2000 & Wiles and Costello & 2000 \\
\hline Hakim et al & 2001 & Clarke & 2002 \\
\hline Town et al & 2003 & Brooke & 2004 \\
\hline Bowers et al & 2005 & Yang & 2006 \\
\hline Armitage & 2007 & & \\
\hline
\end{tabular}


Modifying grid layouts using road closures has been employed as a successful crime prevention strategy (Matthews, 1992; Newman, 1995, Lasley, 1998; Zavoski et al., 1999) and this effectively converts some grid elements into operational cul-de-sacs. In Miami, criminologists Atlas and Le Blanc (1994) reported on the closure of sixty-seven streets and found significant reductions in burglaries, larceny and auto theft, but no significant reductions in recorded robberies and assaults compared with two control areas. Newman's (1996) study of the changes to a grid street layout in the Five Oaks neighbourhood in Ohio found that total recorded crime in the city rose one per cent while in the target neighbourhood recorded crime declined by twenty-six per cent and violent crime declined by fifty per cent. Half of the residents stated that fear of crime had been reduced and Newman reported that housing values had increased. In London, two attempts to reduce street-level prostitution used road closures, rerouting and an increased police presence. After road closures (and an increase in policing prior to the road closures) in Finsbury Park, soliciting and kerb-crawling virtually disappeared (with little recorded displacement) and reported crime fell by fifty per cent (Matthews, 1992). In Streatham a similar project reported a decline in traffic flows along major thoroughfares, a reduction in arrests of kerb-crawlers (although there may be several explanations for this) and residents reported a decline in prostitution at street level (Matthews, 1993). Sheard (1991) studied children's pathways in a Vancouver (Canada) suburb, finding that the introduction of new pedestrian pathways connecting the ends of cul-de-sacs led to increases in crime, since the modifications effectively created through roads for both residents and others. Eck (2002, p277) reviewed a range of evidence associated with street closures and concluded 'the street closure evaluations used moderately strong designs and their conclusions are consistent with theory and prior research. This gives us confidence that street closings are promising'.

\section{Permeability and Other Planning Considerations}

In presenting this evidence, it is necessary to point out that in order to balance security and sustainability, adopting a 'single-issue' approach is neither robust nor appropriate. It is arguable that in many of these studies, although crime may have been reduced, other issues, such as walkability, for example, may have been adversely affected. Such concerns (and others) may not have been subject to measurement or scrutiny, such that urban vitality and residents' well-being may have actually been reduced despite reductions in recorded crime. Adopting a single-issue approach therefore fails to consider potential conflicts and contradictions which may exist in relation to other planning considerations.

It is therefore necessary to review some of the evidence associated with permeability and other planning issues, such as walkability, physical activity, obesity, connectivity, social interaction, housing preferences, traffic congestion, transport behaviour, traffic safety, ecology and land use and infrastructure costs. In a review by Cozens and Hillier (2008), the grid and the cul-desac configurations were analysed and compared in terms of these issues and the claims made by New Urbanism and current planning policy were evaluated. Although a detailed review is beyond the scope of this paper, the basic findings are summarized in Table 2. Clearly, there are numerous assumptions about both the role and effectiveness of permeability as a sustainabilityenhancing mechanism that have not yet been subject to critical inspection and empirical testing. Furthermore, much of the research is contradictory and there is support for limiting permeability, for reasons other than crime reduction, such as traffic safety, ecology, housing preferences, transport behaviour and land-use and infrastructure costs.

Significantly, Southworth and Ben-Joseph (2004) report that in many American cities which possess the connectedness, walkability and accessible land-use patterns, the problems of traffic congestion, noise pollution and road hazards have resulted in the conversion of the grid layout into cul-de-sac patterns using devices such as bollards and concrete planters. In their reexamination of the cul-de-sac Southworth and Ben-Joseph conclude; 'rather than tossing out 
the cul-de-sac as an urban pattern, it is worth reconsidering its values and possibilities in creative ways' (2004, p33).

Table 2: Permeability and its Relationship with Sustainability Issues

\begin{tabular}{|c|c|c|}
\hline Issue & Findings & Authors \\
\hline Walkability & $\begin{array}{l}\text { Permeable streets reduce both travel distance and } \\
\text { travel time, extend public transport use and lessen } \\
\text { car-dependency }\end{array}$ & $\begin{array}{l}\text { Kulash et al., (1990); Gordon } \\
\text { and Peers, (1991); McNally and } \\
\text { Ryan, (1992) }\end{array}$ \\
\hline $\begin{array}{l}\text { Physical } \\
\text { activity }\end{array}$ & $\begin{array}{l}\text { More compact urban environments with mixed uses } \\
\text { and interconnected streets are associated with higher } \\
\text { levels of physical activity }\end{array}$ & $\begin{array}{l}\text { Frank et al, (2004); Saelens et } \\
\text { al., (2003); Shriver, (1996) }\end{array}$ \\
\hline Obesity & $\begin{array}{l}\text { More compact urban environments with mixed uses } \\
\text { and interconnected streets are associated with lower } \\
\text { levels of obesity }\end{array}$ & $\begin{array}{l}\text { Saelens et al., (2003); Frank et } \\
\text { al., (2003); Frank et al., (2005) }\end{array}$ \\
\hline Connectivity & $\begin{array}{l}\text { Connectivity was higher for grid layouts and } \\
\text { estimate that walking distances can be } 40 \% \text { longer } \\
\text { for isolated cul-de-sac layouts. }\end{array}$ & Randall and Baetz (2001) \\
\hline $\begin{array}{l}\text { Social } \\
\text { interaction }\end{array}$ & $\begin{array}{l}\text { Social interaction and a sense of community may be } \\
\text { higher in grid layouts } \\
\text { Cul-de-sac layouts can promote neighbourliness, } \\
\text { familiarity and interaction }\end{array}$ & $\begin{array}{l}\text { Hillier and Shu, (2000) } \\
\text { Sanoff and Dickerson, (1971); } \\
\text { Smith, (1973); Appleyard, } \\
\text { (1981); Je, (1986) }\end{array}$ \\
\hline $\begin{array}{l}\text { Housing } \\
\text { preferences }\end{array}$ & $\begin{array}{l}\text { Cul-de-sacs were preferred even by residents living } \\
\text { on grid and loop layouts } \\
\text { Homebuyers desire properties on cul-de-sacs and } \\
\text { also believe them to be safer, quieter and more } \\
\text { secure from crime. }\end{array}$ & $\begin{array}{l}\text { Ben-Joseph (1995); Morrow- } \\
\text { Jones et al., (2004) } \\
\text { Southworth and Ben-Joseph, } \\
\text { (2003); (2004); Morrow-Jones } \\
\text { et al., (2004) }\end{array}$ \\
\hline $\begin{array}{l}\text { Traffic } \\
\text { congestion }\end{array}$ & $\begin{array}{l}\text { Grid systems can potentially ease congestion on } \\
\text { main thoroughfares but generate additional through } \\
\text { traffic on residential streets travelling at excessive } \\
\text { speeds, which challenges both pedestrianisation and } \\
\text { social integration. }\end{array}$ & $\begin{array}{l}\text { Kulash, (1990), } \\
\text { McNally and Ryan, (1992); } \\
\text { Crane, (1996) }\end{array}$ \\
\hline $\begin{array}{l}\text { Transport } \\
\text { behaviour }\end{array}$ & $\begin{array}{l}\text { Street patterns do not necessarily affect levels of car } \\
\text { use }\end{array}$ & $\begin{array}{l}\text { Crane, (1996); Crane and } \\
\text { Crepeau, (1998) }\end{array}$ \\
\hline Traffic safety & $\begin{array}{l}\text { Residents living in cul-de-sacs experience lower } \\
\text { levels of risk than residents of grid layouts }\end{array}$ & $\begin{array}{l}\text { Southworth and Ben-Joseph, } \\
\text { (2003), (2004) }\end{array}$ \\
\hline Ecology & $\begin{array}{l}\text { Disconnected cul-de-sac layouts adapt better to } \\
\text { topography and can work around areas of premium } \\
\text { ecological or historical value thereby contributing to } \\
\text { sustainability. }\end{array}$ & $\begin{array}{l}\text { Ben-Joseph, (1997); } \\
\text { Southworth and Ben-Joseph, } \\
\text { (2003), (2004) }\end{array}$ \\
\hline $\begin{array}{l}\text { Land use and } \\
\text { infrastructure } \\
\text { costs }\end{array}$ & $\begin{array}{l}\text { The proportion of development land taken up by } \\
\text { roads in cul-de-sacs is lower than that of grid grids } \\
\text { and that utility costs are also lower. }\end{array}$ & $\begin{array}{l}\text { Girling and Helphand, (1994) } \\
\text { Wells, (1993) }\end{array}$ \\
\hline
\end{tabular}




\section{The Research Findings: PAWs, Crime and Walkability}

A study into PAWS was recently undertaken by the authors, funded by the Office of Crime Prevention in WA. The research was directed at providing practical guidance to local governments on how they could better manage existing pedestrian access ways (PAWs), particularly those considered to have crime related effects, such as vandalism, anti-social behaviour and prostitution while also providing potential burglars with rear access to properties. The issue had become highly politicized when one of WA mayors highlighted crime problems associated with PAWs in a letter to all the government departments and the Premier. The only planning mechanism that existed was Planning Bulletin 57 (WAPC, 2003) and whose scope is limited to procedures for closing a PAW based on the Western Australian Planning Commission's version of a ped-shed analysis, which attempt to measure levels of connectivity in a particular manner.

PAWs are specific physical elements of urban, suburban and peri-urban space. In particular, PAWs are physical elements of the walking network used alongside other features such as road and street footpaths, lanes, public open space, beaches, and pseudo-public spaces such as shopping centres, rail and bus stations. Some PAWs and many laneways and alley-ways are pseudo-public space in that they are privately owned and access through them is permitted by the owners subject to behaviour and individual access rules that the owners devise. The majority of PAWs of concern, however, are narrow pedestrian path PAWs that are dominated by public space and equity considerations (White, 2004).

The authors reviewed national and international literature relating to PAWs and undertook a saturation analysis of PAW types and informal inspection of multiple PAWs at specific locations throughout metropolitan Western Australia. This involved the use of local area maps, site inspections and photographic review of over one hundred PAWs. A morphological analysis of existing PAWs was undertaken and analysed the purposes, roles, users and dynamics of PAW use in a variety of circumstances. This process involved exploring the planning, legal, ownership and control issues relating to PAWs and the identifying the applicability of Design Out Crime/CPTED approaches to managing PAWS. Finally, the authors developed a range of assessment tools and a decision tree for managing PAWS.

Contrary to many assumptions, the research indicated that only a small minority of PAWs were subject to high levels of crime and anti-social behaviour. Others were merely perceived to be associated with crime and most were relatively safe and unproblematic. However, recorded crime statistics were not available at this scale of analysis and clear unequivocal evidence of the presence of crime and anti-social behaviour was absent.

The effective functioning of PAWs is important for the Australian community. It is a significant issue in terms of government policies encouraging increased levels of walking and cycling along with reductions in car use. Considering the highly unique and situational nature of each PAW, various issues, such as walkability, required consideration in addition to crime and the fear of crime.

In any particular PAW, crime or fear of crime acts to reduce its proper functioning and can present considerable concern to PAW users and those living in nearby residences. Addressing crime and antisocial behaviour associated with PAWs and making decisions about the criminological significance of PAWs requires accurate information about the physical aspects of the individual PAW, and the local context of its uses, purposes, roles and users as they change during the day, week and year. Understanding the crime status of a PAW requires accurate and reliable crime data, which was problematic, since police-recorded crime data was not available at the microscopic level of analysis. Instead, it was necessary to develop 
alternative tools that included crime concerns in PAW assessment and identified best-case strategies for reducing crime using Designing Out Crime initiatives.

The researchers developed a Situational Crime Prevention Assessment (SCPA) for PAWs that comprises a suite of 5 tools for assessing and reducing crime risks in PAWs:

1. Designing Out Crime PAW Assessment (DOCPA)

2. Contextual Crime Assessment (CCA)

3. Socio-Economic Vulnerability Assessment (SEVA)

4. PAW Use and Context Assessment (PUCA)

5. Decision Tree

These five tools are designed to provide planners with the responsibility for managing PAWs, with a means of collected relevant data and enabling a more informed assessment of how to best manage any individual PAW.

\section{The Research Findings: The Designing Out Crime PAW Assessment}

The Designing Out Crime PAW Assessment (DOCPA) provides planners and decision makers with a detailed, straightforward and rapid snapshot about the potential vulnerability of a PAW to crime in terms of use, crime problems and design factors associated with discouraging or encouraging crime. The DOCPA illustrated in Figure 1 provides the basis for an initial crime risk audit of an individual PAW.

Figure 1: Designing Out Crime PAW Assessment (DOCPA)

\begin{tabular}{|l|l|l|}
\hline Risk Criteria & Yes & No \\
\hline 1. The PAW is overlooked at its entrance. & & \\
\hline 2. The PAW is overlooked at its exit. & & \\
\hline 3. The PAW is overlooked along its route. & & \\
\hline 4. Do PAW users feel the safety of being overlooked? & & \\
\hline 5. Does the PAW have adequate lighting? (facial recognition at 10m distance) & & \\
\hline 6. On entering the PAW, can you see the exit? & & \\
\hline 7. The PAW is devoid of entrapment spots or hiding places along it. & & \\
\hline 8. The PAW is devoid of entrapment spots within 25m of each end of the PAW. & \\
\hline 9. The PAW is appropriately-maintained. & \\
\hline 10. The boundaries between public space and private space are clearly defined. & \\
\hline 11. The boundaries between public space and private space are robustly fenced. & \\
\hline 12. Does the PAW have signs indicating acceptable behaviour? & \\
\hline 13. The PAW is free from people sleeping / living in the PAW. & & \\
\hline 14. The PAW is wide enough to allow pedestrians to pass at a distance of 3m apart. & \\
\hline 15. The PAW is NOT adjacent to vacant land or property & \\
\hline 16. The PAW is NOT a direct connection between affluent and deprived areas. & \\
\hline 17. The PAW is NOT close to a supplier of alcohol (liquor store, hotel, tavern, bottle shop etc) & & \\
\hline 18. The PAW is NOT a path to a high school. & \\
\hline 19. The PAW is NOT close to an ATM, public telephone box or public toilet. & \\
\hline & & \\
\hline
\end{tabular}


A planning officer, preferably with adequate training in CPTED (or perhaps with the assistance of a local police officer) would visit a specific PAW and walk along it and survey the entrance, the exit and the full length of the access way itself. Upon visual inspection and subjective evaluation, the questions would then be answered as Yes or No. In terms of the total number of 'yes' responses, a PAW with a high DOCPA (low vulnerability to crime) would score fourteen to nineteen. A PAW with medium vulnerability to crime scores six to thirteen and a PAW with a low DOCPA rating exhibiting a 'high' vulnerability to crime, scores zero to five.

\section{The Research Findings: Contextual Crime Assessment}

Accurate information on actual and perceived levels of crime associated with the PAW is important as a crucial backdrop to decision-making about interventions aimed at reducing crime and anti-social behaviour. It is uneconomic to commit resources to crime prevention or improving the security of a PAW that does not have a crime problem. Figure 2 below indicates information that must be gathered.

\section{Figure 2: Crime and fear of crime from PAW users and those living or working nearby.}

Gather information from reliable sources (police, court records) about actual crime activities associated with the PAW.

1. Collect data on recorded crimes against users of the PAW

2. Collect data on recorded crime involving damage of the PAW

3. Collect data on recorded crimes against properties on or near to the PAW

Survey a fully representative sample of PAW users (different PAW user groups) and those living and working near to the PAW about their fear of crime. If necessary, use professional data collection services for this.

1. Collect data on the fear of crime of PAW users (for different user groups)

2. Collect data on the fear of crime of those living and working near to the PAW

A key issue in understanding the crime risk of an individual PAW is the combination of the relative physical vulnerability of a PAW and the relative socio-economic index of the users of that PAW.

\section{The Research Findings: Socio-Economic Vulnerability Assessment}

The Australian Bureau of Statistics’ Socio-Economic Index for Areas (SEIFA) offers a surrogate for socio-economically related risks for crime and antisocial behaviour. The Index of Relative Socio-Economic Disadvantage can be used alongside the physical analysis of Part 1 (the DOCPA) to provide an assessment of potential vulnerability that is weighted by socioeconomic factors, thus combining social and situational crime assessment.

Assessment of PAW risk associated with any PAW can be represented in terms of a fourquadrant chart (see Figure 3 below) to identify whether a PAW is likely to be of high or low crime risk due to the socio-economic context. The focus is on the users of a PAW. In the case of PAWs, such as semi-private, shared access laneway PAWs, where the users live abutting the PAW, the address of the PAW provides the basis for the SEIFA rating. 
Figure 3: Socio-Economic Vulnerability Assessment (SEVA)

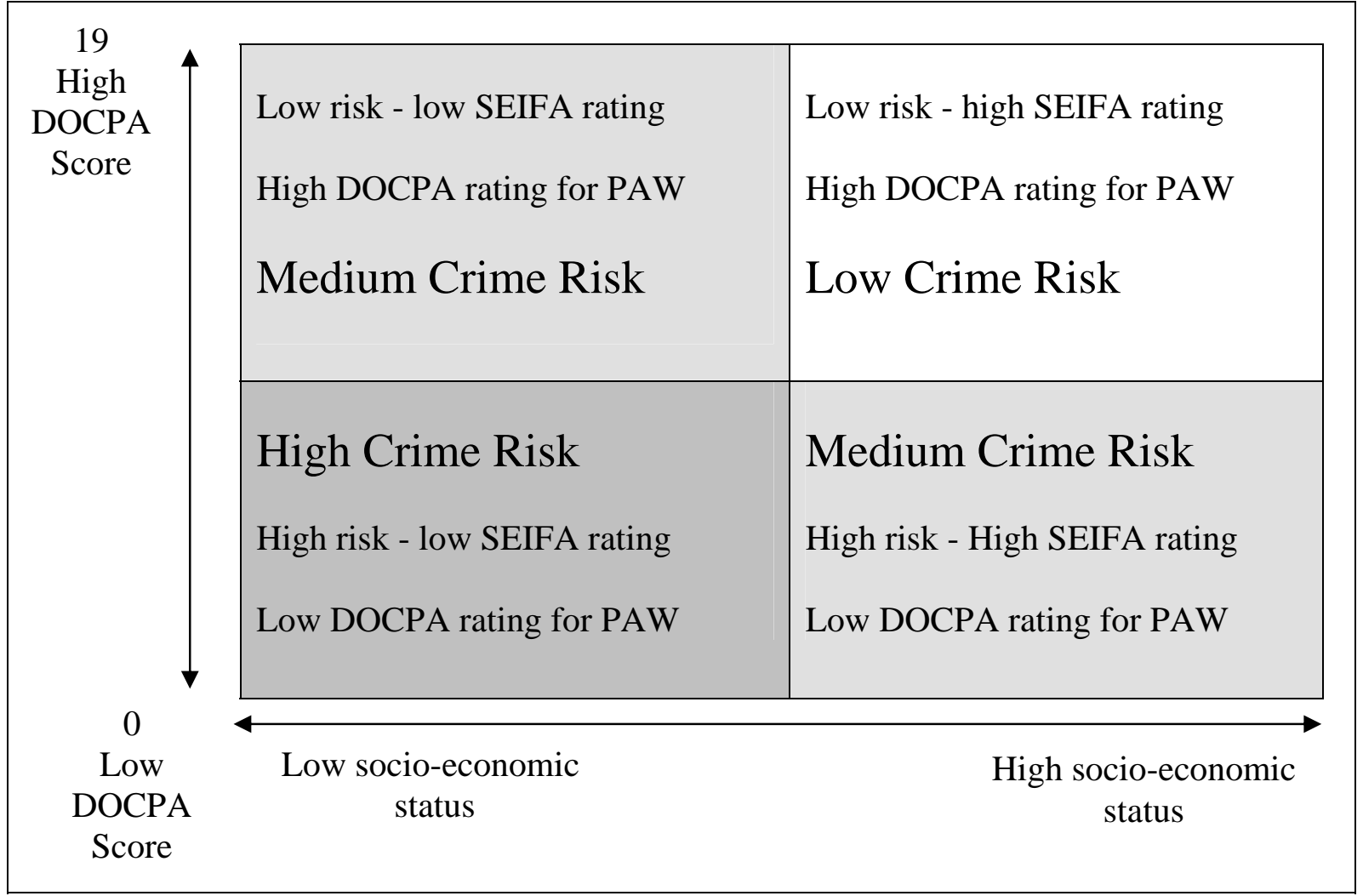

\section{The Research Findings: PAW Use and Context Assessment}

For many PAWs, some or all user groups are likely to come from outside the immediate PAW location. In these cases, the findings from Part 4 of the SCPA (the PUCA) will identify the user groups, their location and use of the PAW in ways that enable the SEVA to be applied appropriately.

PAWs have many roles and uses and Part 4, the PAW Use and Context Assessment (PUCA) is investigated to encourage local authorities to probe this crucial dimension. Six cases were provided to illustrate some of the benefits of understanding the use and contexts of an individual PAW for identifying appropriate crime prevention strategies. Most PAW roles and uses are functionally useful at a daily level for families in the Australian community: e.g. providing access to buses, shops and schools and as components of healthy walking and cycling routes. For the few PAWs that experience more than normal low-level background crime, crime-related issues occupy a very small slice of the overall PAW usage and are typically localised to a very small group of PAW users and occur across a very limited range of times.

It is possible to maintain the benefits of PAW use whilst managing crime issues in a particular PAW by understanding the pattern of use of the PAW, the different groups of users, the different PAW roles, the PAW's special importance in foot traffic terms, and the timedynamics associated with its usage. This enables crime reduction interventions to accurately target the problematic times and uses.

The PAW Use and Context Assessment asks a range of qualitative questions that can then guide the use of quantitative information from other parts of the SCPA. Example questions are shown in Figure 4 below: 
Figure 4: PAW Use and Context Assessment: typical questions

\begin{tabular}{|l|}
\hline PAW Use and Context Assessment Questions \\
\hline What are the main uses of the PAW? \\
\hline Which groups use the PAW? \\
\hline How important is PAW use by groups from outside of the neighbourhood? In what ways? \\
\hline What is the distribution of use of the PAW for different purposes/roles - across the day, week and year? \\
\hline Is the PAW part of a longer path or extended informal and formal network of paths and cycle paths (PCAPs)? \\
\hline Is the PAW a significant node that carries traffic for other PAWs? \\
\hline $\begin{array}{l}\text { Is this PAW close to point of interest (shops, bottle shop, bus stop, train station, church, beach, sports stadium } \\
\text { etc) }\end{array}$ \\
\hline Is the PAW a triple 'H' PAW (higher use, higher user importance, higher crime)? \\
\hline How different is the confirmed crime/antisocial behaviour rate of the PAW from that of nearby streets? \\
\hline What are the time dynamics of crimes directly associated with the PAW? Evening? Night? Morning? Daytime? \\
\hline $\begin{array}{l}\text { If there is an application for closure, how is the ethical integrity of the application? Is it driven by profiteering } \\
\text { or by an excessive level of crime that cannot be addressed by CPTED or DOC or in any other way? }\end{array}$
\end{tabular}

\section{The Research Findings: the Decision Tree}

The Decision Tree follows a five stage process that aligns with the structure of PB57:

1. Complaint received

2. Assess usage

3. Assess actual and perceived crime

4. Assess and apply Design Out Crime design qualities

5. Assess and implement other strategies

The initial issue focuses on how 'essential' the PAW is. An assessment of the PAW using steps 3-9 in the Appendix of PB57 provides guidance on this. There are two important indices in the decision between improvement and closure. Firstly, a PAW that is 'essential' and well-used (Risk Criteria A) should not be considered for closure. In terms of the user groups and communities that use the PAW and in planning terms, these are vital. Criteria for defining PAWs (including an 'essential' PAW) are provided in Appendix 1 of PB57.

If the PAW is designated 'non-essential' or 'retain', various Designing Out Crime options are still available. Only PAWs where there is demonstrable evidence of high levels of actual and perceived crime should be considered for closure (Risk Criteria B). If there is evidence of actual or perceived crime risk (not necessarily both), temporary or permanent closure is an option. The findings from this research have recently been published in the form of planning guidelines for local government entitled 'Reducing Crime and Anti-Social Behaviour in Pedestrian Access Ways' (WAPC, 2009) - which will give them the capacity to improve existing PAWs, close highly problematic PAWs and potentially, consider providing new PAWs where connectivity might require strengthening.

No two PAWs are identical, their design, use and functionality are different and consequently, the problems associated with them and the solutions applied to them will need to be different to respond appropriately and effectively to the local context. For each PAW, this requires identifying the users, roles, purposes, functions, user groups and distribution of different uses and user-groups during the day, week and year.

The research indicated that maximizing the outcomes in the management of PAWs emerges from a government approach that aims to support the achievement of all the agendas of government agencies and public interests. Contrary to the previous policy direction, this is likely to require the retention of PAWs and perhaps an increase in the number of PAWs, especially in many post-war convoluted suburbs. 
In summary, the research undertaken to produce 'simple guidelines', was far from simple and challenged initial assumptions on the vulnerability of PAWs to crime and the importance and role of PAWs to the community. The findings also indicated that neighbourhood permeability can potentially be manipulated (via the management, closure or opening of PAWs) to achieve the desired outcomes of reducing crime and of enhancing walkability, liveability and ultimately, the sustainability and well-being of communities.

\section{Discussion: Permeability and Crime}

Clearly, the permeability debate is highly complex and the discussion has focused too simplistically on considering single issues in isolation. It is therefore useful to set out some of the assumptions associated with key issues such as Jacob's 'eyes on the street', how strangers are interpreted and the relevance of levels and type of pedestrian use (see Table 3).

\section{Table 3: Assumptions in the 'Enclosure versus Encounter' Debate}

\begin{tabular}{|l|l|}
\hline Enclosure Model (limiting permeability) & Encounter Model (maximizing permeability) \\
\hline $\begin{array}{l}\text { Jacob's concept of 'eyes on the street' applied to } \\
\text { personal attacks, but has been adapted for all } \\
\text { types of crime. }\end{array}$ & $\begin{array}{l}\text { Jacob's concept of 'eyes on the street' applied to } \\
\text { personal attacks, but has been adapted for all types } \\
\text { of crime. }\end{array}$ \\
\hline $\begin{array}{l}\text { Strangers are all 'bad' - and they weaken the } \\
\text { defensibility of an area }\end{array}$ & $\begin{array}{l}\text { Strangers are all 'good' - and they strengthen the } \\
\text { defensibility of an area }\end{array}$ \\
\hline $\begin{array}{l}\text { All residents are 'good' and they strengthen the } \\
\text { defensibility of an area. }\end{array}$ & $\begin{array}{l}\text { All residents are 'good' and they strengthen the } \\
\text { defensibility of an area. }\end{array}$ \\
\hline $\begin{array}{l}\text { Residents are home to observe potential offending } \\
\text { in the street }\end{array}$ & $\begin{array}{l}\text { Residents are home to observe potential offending } \\
\text { in the street }\end{array}$ \\
\hline $\begin{array}{l}\text { Residents are home and are actively watching the } \\
\text { street }\end{array}$ & $\begin{array}{l}\text { Residents are home and are actively watching the } \\
\text { street }\end{array}$ \\
\hline $\begin{array}{l}\text { Residents can recognise strangers amongst other } \\
\text { users in cul-de-sacs }\end{array}$ & $\begin{array}{l}\text { Residents can recognise strangers amongst other } \\
\text { users on busy grid street layouts }\end{array}$ \\
\hline $\begin{array}{l}\text { Residents are not 'apathetic bystanders' and will } \\
\text { intervene }\end{array}$ & $\begin{array}{l}\text { Residents are not 'apathetic bystanders' and will } \\
\text { intervene }\end{array}$ \\
\hline $\begin{array}{l}\text { Offenders are dissuaded from offending by the } \\
\text { potential for observation by residents }\end{array}$ & $\begin{array}{l}\text { Offenders are dissuaded from offending by the } \\
\text { potential for observation by residents }\end{array}$ \\
\hline Strangers avoid cul-de-sacs & $\begin{array}{l}\text { Connected / permeable streets are well-used by } \\
\text { legitimate users }\end{array}$ \\
\hline $\begin{array}{l}\text { Offenders are not local residents living in the cul- } \\
\text { de-sacs, and travel from elsewhere }\end{array}$ & $\begin{array}{l}\text { Offenders are not local residents living in the grid } \\
\text { network, and travel from elsewhere }\end{array}$ \\
\hline $\begin{array}{l}\text { All residents act as 'capable guardians' and } \\
\text { will report incidence or intervene if necessary } \\
\text { ill residents act as 'capable guardians' and } \\
\text { will report incidence or intervene if necessary }\end{array}$ \\
\hline $\begin{array}{l}\text { All cul-de-sacs are non-permeable } \\
\text { higher levels of territoriality }\end{array}$ & $\begin{array}{l}\text { All cul-de-sacs are non-permeable } \\
\text { higher levels of territoriality }\end{array}$ \\
\hline
\end{tabular}

Perhaps the most fundamental assumption that both models have made is to adopt Jane Jacobs' (1961) ideas, carte blanche, to every context. Jacobs (1961) observations focused on inner city areas of large American cities in the 1950s whereby high levels of social integration 
underpinned the process of 'eyes on the street'. Critically, Jacobs (1961, p26) commented, 'I hope no reader will try to transfer my observations into guides as to what goes on in towns, or little cities, or in suburbs which are still suburban'.

Crucially, the theoretical foundations for supporting permeability as a crime reduction strategy are founded on the promotion of activity and 'eyes on the street'. This concept of self policing may (or may not) work effectively in large vibrant cities, but it is certainly likely to be weakened in less densely populated suburbs with reduced levels of pedestrian and vehicular movement. It may also work less effectively in large cities where social integration is not strong.

It is argued that by understanding some of these assumptions, planners and criminologists will be potentially better informed and can make more robust decisions relating to the issue of permeability. Indeed, many of these assumptions require subsequent rigorous scientific testing in future research projects.

Jacobs' interest was in personal attacks (Poyner, 2006) but the crime prevention concept of 'eyes on the street' has since been applied to all types of crime. Although increased numbers of pedestrians may provide additional 'eyes on the street' and potentially discourage some offences, this may also actually encourage and provide other targets for crime (e.g. pickpocketing). Sorensen (2003, p. 34) observes, 'pedestrian traffic thus seems to increase risk (from the standpoint of target selection) and decrease risk (from the standpoint of natural surveillance) depending on whether that traffic is through traffic or local traffic'.

\section{Conclusions}

Brantingham and Brantingham (1998, p53) argued that environmental criminology should be more explicitly considered within the planning realm stating 'most planning proceeds with little knowledge of crime patterns, crime attractors, crime generators, the importance of edges, paths and nodes or the site specific conditions that facilitate or even encourage crime'. Similarly, criminologists should also be more aware of issues other than crime and fear of crime that have to be considered and incorporated by planners, urban designers and built environment professionals.

How then, can these two seemingly contradictory perspectives be reconciled? In simple terms, resolution appears possible through analysing situations at the local level and by thinking beyond single-issue agendas. The SCPA approach developed for the PAW research attempted to do this by providing local governments with a set of tools to more accurately diagnose local problems / issues and to apply more appropriate solutions at the highly localised level.

It is therefore suggested that rather than being a dichotomous decision between permeable and non-permeable, planners and criminologists might think about manipulating the extent of street permeability at the local context to optimise outcomes. This approach is supported by Schneider and Kitchen (2002, p. 225) who suggested that it is about choice and that 'although there is a clear clash of ideas here, that does not mean that they cannot co-exist'.

In summary, there are many single-issue perspectives relating to the issue of permeability and the built form and research is not necessarily always conclusive. There are many assumptions inherent within these diverse fields of research that researchers are continuing to test and to challenge. What all seek to do is to investigate and measure the relationship between the built form and certain types of human behaviour, and there are many lessons that could be exchanged across disciplines on key issues such as definitions, methodology, measurement and inferring causality. 'Single-issue' investigations can be subject to contradictions that can work against the findings of research and subsequent policy making in regard to other single issues and this can affect desired outcomes. What is therefore required is multi-issue and multi- 
disciplinary research into specific and localized aspects of the built form and how it might affect a range of behaviours (including crime).

There are a range of recommendations emerging from this research for consideration by local government councils, security departments and planning officers as well as developers, architects, transport planners and economic development planners. The knowledge generated by this research is summarised in the WAPCs planning guidelines Reducing Crime and AntiSocial Behaviour in Pedestrian Access Ways (2009) which have been prepared as a supplement to the Designing Out Crime Planning Guidelines.

The recommendations for further research are directed at policy-makers, researchers and practitioners from both security and sustainability agendas.

\section{Recommendations for Balancing Sustainability and Security}

- To develop improved frameworks for measuring permeability and measuring the level of use of street networks;

- To challenge the sustainability agenda to engage with the evidence from across disciplinary boundaries, particularly environmental criminology;

- To systematically review the quality of evidence as it applies to walkability in a range of urban and suburban settings;

- To promote inter-agency and inter-disciplinary collaboration concerning research, which considers placed-based factors and attitudinal dimensions to understanding the dynamics of the people-place relationship;

- To undertake an empirical and contemporary review of Jane Jacobs' ideas, including 'eyes on the street' (1961) as this may relate to specific types of crime, to modern suburban residential settings and to urban centres in smaller towns and cities in the twenty-first century.

- To conduct research on perceptions of CPTED/Designing Out Crime in different cultures and for different stakeholders in the rapidly urbanizing developing world. 


\section{References}

American Planning Association. (2007) Legislation and policy. Available at http://www.planning.org/policyguides/smartgrowth.htm Accessed 7th July 2008.

Appleyard, D. (1981) Livable Streets. Berkeley: University of California.

Armitage, R. (2000) An evaluation of secured by design within West Yorkshire. Home Office Briefing Note 7/00. London, Crown Copyright.

Armitage, R. (2007) Sustainability versus safety: confusion, conflict and contradiction in designing out crime, in G. Farrell, K. Bowers, S. Johnson \& M. Townsley (Eds) Imagination for Crime Prevention: Crime Prevention Studies 21, pp 81-110. Monsey, NY: Criminal Justice Press.

Atlas, R. and LeBlanc, W. (1994) The impact on crime of street closures and barricades: a Florida case study. Security Journal, 5(3), pp. 140-5.

Barnyard, V. (2008) Measurement and correlates of pro-social bystander behaviour: the case of interpersonal violence. Violence and Victims, 23(1), pp. 83-97.

Beavon, D. J. K. (1984) Crime and the Environmental Opportunity Structure: The Influence of Street Networks on the Patterning of Property Offences. Unpublished M.A. Thesis, Simon Fraser University, Burnaby, British Columbia.

Beavon, D., Brantingham, P. \& Brantingham, P. (1994) The influence of street networks on the patterning of property offenses, in R. Clarke (Ed), Crime Prevention Studies, 2 (Monsey, NY: Criminal Justice Press).

Ben-Joseph, E. (1995) Livability and safety of suburban street patterns: a comparative study, Working Paper 64, Berkeley Institute of Urban and Regional Development and University of California Institute of Transportation Studies.

Ben-Joseph, E. (1997) Traffic Calming and the neotraditioal street. Resource papers for the 1997 Institute of Transportation Engineers. International Conference, pp. 47-52. Available at http://www.ite.org/traffic/ documents/CCA97A47.pdf. Accessed 20 $0^{\text {th }}$ march 2008.

Bevis, C., and Nutter, J. (1978) Changing street layouts to reduce residential burglary. Minneapolis: Minnesota Crime Prevention Center.

Black, A. (2004) The quest for sustainable healthy communities. Paper presented at the Effective Sustainability Education: What Works? Why? Where Next? Linking Research and Practice Conference, Sydney, Australia, $18-20^{\text {th }}$ February.

Bowers, K., Johnson S. and Hirschfield, A. (2005) Closing off opportunities for crime: an evaluation of alley-gating. Journal European Journal on Criminal Policy and Research. 10(4) pp. 285-308.

Brantingham, P.J. and Brantingham, P.L. (2000) A Conceptual model for anticipating crime displacement. Paper presented at the American Society of Criminology Conference, San Fransisco.

Brantingham, P.J. and Brantingham, P.L. (1998) Environmental criminology: from theory to urban planning practice. Studies on Crime and Crime Prevention, 7(1), pp. 31-60.

Brantingham, P. J. \& Brantingham, P. L. (1993) Nodes, paths and edges: considerations on the complexity of crime and the physical environment, Journal of Environmental Psychology, 13, pp. 3-28. 
Brantingham, P. J., Brantingham, P. L. \& Molumby, T. (1977). Perceptions of crime in a dreadful enclosure. Ohio Journal of Science, 77, pp. 256-261.

Brantingham, P. L. \& Brantingham, P. J. (1975). Residential burglary and urban form. Urban Studies, 12, 273-284.

Brooke, M. (2004) Mallard Court, Bradford: A paper presented at the Architectural Liaison Officers' Conference, Leeds, UK.

Brown, B. \& Altman, I. (1983) Territoriality, defensible space and residential burglary: an environmental analysis. Journal of Environmental Psychology, 3, pp. 203-220. Toronto: Toronto Press.

Brown, J. (1999). An evaluation of the secured by design initiative in Gwent, South Wales, MSc, Scarman. Leicester: Centre for the Study of Public Order, University of Leicester.

Clarke, R. (2002) Closing streets and alleys to reduce crime: should you go down this road? Problem-oriented guides for police response guides series No. 2. U.S. Department of Justice Office of Community Oriented Policing Services. Available at www.cops.usdoj.gov. Accessed on $3^{\text {rd }}$ June 2005.

Coleman, A. (1985) Utopia on Trial. London: Hilary Shipman Ltd

Commonwealth of Australia. (1995) AMCORD: A National Resource Document for

Residential Development Commonwealth of Australia, Department of Housing and Regional Development.

Cozens, P. (2002) Sustainable urban development and crime prevention through environmental design for the British city: towards an effective urban environmentalism for the 21st century. Cities: The International Journal of Urban Policy and Planning. 19(2), pp. 129-137.

Cozens, P. (2008a) Crime prevention through environmental design (CPTED) in Western Australia: planning for sustainable urban futures. International Journal of Sustainable Development and Planning, 3(3), pp. 272-292.

Cozens, P. (2008b) New urbanism, crime and the suburbs: a review of the evidence. Urban Theory and Practice 26(3), pp 1-16.

Cozens, P., Pascoe, T. and Hillier, D. (2004). Critically reviewing the theory and practice of secured-by-design for residential new-build housing in Britain. Crime Prevention and Community Safety: An International Journal, 6(1), pp 13-29.

Cozens, P. Saville, G. and Hillier, D. (2005). Crime prevention through environmental design (CPTED): A review and modern bibliography. Journal of Property Management 23 (5), pp 328-356.

Cozens, P., Pascoe, T. and Hillier, D. (2007) Critically reviewing the theory and practice of secured-by-design for residential new-build housing in Britain. Burglary: International Library of Criminology, Criminal Justice and Penology - Second Series, (Ed.) Mawby, R. Ashgate, Hampshire, England, pp.345-361.

Cozens, P. and Hillier, D. (2008) The shape of things to come': new urbanism, the grid and the cul-de-sac. International Planning Studies Volume 13(1), pp. 51-73.

Crane, R. \& Crepeau, R. (1998) Does neighbourhood design influence travel?: Behavioural analysis of travel diary and GIS data. Working Paper UCTC No. 374. University of California Transportation Centre, Berkley. Available at http://www.uctc.net/papers/374.pdf. Accessed, May 24th 2008. 
Crane, R. (1996) On form versus function: will the new urbanism reduce traffic or increase it? Journal of Planning Education and Research, 15, pp. 117-126.

Cromwell, P. F., Olson, J. N. \& Avary, D. W. (1991) Breaking and entering: an ethnographic analysis of burglary. Newbury Park, CA: Sage Publications.

Darley, J. M., and Latane, B. (1968) Bystander intervention in emergencies: diffusion of responsibility. Journal of Personality and Social Psychology, 8,pp. 377-383.

DETR. (1998) Places, streets and movement: a companion guide to design bulletin 32: residential roads and footpaths, London: HMSO.

Dewberry, E. (2003) Designing out crime: insights from eco-design. Security Journal, 16(1), pp. 51-62, 2003.

Dovey, K. (1998) Safety and danger in urban design. Paper presented at the conference Safer Communities: Strategic Directions in Urban Planning. Convened jointly by the Australian Institute of Criminology and the Victorian Community Council Against Violence. Melbourne, 10-11 September.

Du Plessis, C. (1999) The links between crime prevention and sustainable development, Open House International, 24(1), pp. 33-40.

Eck, J. (2002) Preventing crime at places, in Sherman, L., Farrington, D.P., Welsh, B and Mackenzie, D. (Eds.). Evidence-based crime prevention, pp. 9241-294. London and New York: Routledge.

Ekblom, P. (1995) Less crime by design, Annals of the American Academy of Political and Social Science, 539, pp. 114-129.

Ekblom, P. (1997). Gearing up against crime: a dynamic framework to help designers keep up with the adaptive criminal in a changing world. International Journal of Risk, Security and Crime Prevention, 2, pp. 249-65.

Frank, L., Engelke, P. \& Schmid, T. (2003) Health and community design: the impact of the built environment on physical activity. Washington DC: Island Press.

Frank, L., Engelke, P. \& Schmid, T. (2004) Public health and the built environment: emerging evidence and complexity. Insert to the Canadian Journal of Dietetic Practice and Research, 65(2). Available at:

http://www.kelloggnutrition.com/includes/pdf/2004\%20Summer\%20DCIns_Built\%20Environ ment.pdf. Accessed on May $23^{\text {rd }} 2008$.

Frank, L., Schmid, T., Sallis, J., Chapman, J. \& Saelens, B. (2005) Linking objectively measured physical activity with objectively measured urban form: findings from SMARTRAQ, American Journal of Preventive Medicine, 28(2), pp. 117-112.

General Household Survey (1996) Living in Britain. London: HMSO.

Girling, C. \& Helphand, K. (1994) Yard, street, park: the design of suburban open space. New York: Wiley.

Gordon, S. \& Peers, J. (1991) Designing a community for TDM: the Laguna West pedestrian pocket, 71st Annual Meeting of the Transportation Research Board, Washington DC.

Greenberg. S. and Rohe, W. (1984) Neighborhood design and crime: a test of two perspectives. Journal of the American Planning Association 50, pp. 48-60.

Hakin, S., Rengert, G. and Shachamurove, Y. (2001) Target search of burglars: a revisited economic model. Papers in Regional Science, 80, pp. 121-137. 
Hart , T. and Miethe, T. (2008) Exploring bystander presence and intervention in nonfatal violent victimization: when does helping really help? Violence and Victims, 23(5), pp. 637-651.

Herbert, D (1977) Crime delinquency and the urban environment. Progress in Human Geography, 1, pp. 208-239.

Hillier B, and Hanson, J. (1984) The Social Logic of Space. Cambridge: Cambridge University Press.

Hillier, B. (1973) In defence of space. RIBA Journal, 11, November, pp. 539-44.

Hillier, B. (2004) Can streets be made safer. Urban Design International, 9 pp.31-45.

Hillier, B. and Shu, S. (1998) Crime and urban layout: the need for evidence. Home Office Crime Prevention College: Easingwold.

Hillier, B. and Shu, S. (2000) Crime and urban layout: the need for evidence, pp. 224-48, in (Eds) S. Ballintyne, K. Pease, and V. McLaren Secure Foundations: Key Issues in Crime Prevention, Crime Reduction and Community Safety. London, Institute of Public Policy Research.

Jacobs, J. (1961). The Death and Life of Great American Cities, New York: NY, Vintage Books.

Je, Hae-Seong (1986) Urban residential streets: a study of street types and their territorial performances, Unpublished Dissertation. Pennsylvania: University of Pennsylvania.

Jones, M., and Fanek, M., (1997) Crime in the urban environment, Proceedings, 1st International Space Syntax Symposium, Vol. II, London, pp. 25.1-25.11.

Knights, B., Pascoe, T. \& Henchley, A., (2002) Sustainability and crime: managing and recognising the drivers of crime and security, Garston, Watford: Building Research Establishment.

Knowles, P. (2003) The cost of new urbanism. Community Safety Journal. 2(4), pp. 33-38. Available at http://www.americandreamcoalition.org/safety/policingnu/policingnu.html. Accessed January 23rd 2007.

Knowles, P. (2006) Designing out crime - the cost of policing new urbanism. Available at http://www.americandreamcoalition.org/safety/policingnu/policingnu.html. Accessed 10th July 2006.

Kulash, W. (1990) Traditional neighborhood development: will the traffic work? Eleventh International Pedestrian Conference, Bellevue, WA.

Lasley, J. (1998) Designing out gang homicides and street assaults. Washington, D.C: U.S. National Institute of Justice.

Matthews, R. (1992) Developing more effective strategies for curbing prostitution, in (Ed.) R. Clarke, Situational Crime Prevention: Successful Case Studies (New York, Harrow and Heston).

Matthews, R. (1993) Kerb-crawling, prostitution and multi-agency policing, Crime Prevention Unit Series Paper 43 (London, Home Office Police Research Group).

McNally, M. \& Ryan, S. (1992) A comparative assessment of travail characteristics for neotraditional, Resource Papers for the 1997 International Conference 51 Development .University of California, Irvine: Institute of Transportation Studies.

Mirrlees-Black, C., Budd, T., Partridge, S. and Mayhew, P. (1998) The 1998 British Crime Survey. London: HMSO. 
Morgan, C. J. (1978) Bystander intervention: experimental test of a formal model. Journal of Personality and Social Psychology, 36, pp. 43-55.

Morrow-Jones, H., Irwin, E. \& Roe, B. (2004) Consumer preference for neotraditional neighbourhood characteristics, Housing Policy Debate, 15(1), pp. 171-202.

Newlands, M. (1983) Residential burglary patterns in a Vancouver neighborhood. Unpublished honours thesis, Simon Fraser University, British Columbia, Canada.

Newman, O. (1995) Defensible space: a new physical planning tool for urban revitalization, Journal of the American Planning Association, 61, pp. 2149-2155.

Newman, O. (1996) Creating Defensible Space, U.S. Department of Housing and Urban Development, , Washington, DC: Office of Policy Development and Research.

Newman, O. (1973) Defensible Space: People \& Design in the Violent City. London: Architectural Press.

Newman, O. (1980) Community of Interest. Garden City, NY: Anchor Press/Doubleday.

Pascoe, T. (1999) Evaluation of secured by design in public sector housing. Final Report. Watford: Building Research Establishment.

Pascoe, T. and Topping, P. (1998) `Secured by design: assessing the basis of the scheme. International Journal of Risk Security and Crime Prevention, 2(3), pp. 161-73.

Popkin, S., Gwiasda, V., Rosenbaum, D., Anderson, A., Olson, L., Lurigio, A. and Taluc, N. (1995a) An evaluation of the Chicago Housing Authority's anti-drug initiative: a model of comprehensive crime prevention in public housing.. Cambridge, MA: Abt Associates Inc.

Popkin, S., Olson, M., Lurigio, A., Gwiasda, V. and Carter, R. (1995b), Sweeping out drugs and crime: residents' views of the Chicago Housing Authority's public housing drug elimination program. Crime and Delinquency, 41(1), pp. 73-99.

Poyner, B. and Webb, B. (1991) Crime free housing. London: Butterworths-Architecture.

Poyner, B. (2006) Crime free housing in the 21st Century. London: Jill Dando Institute of Crime Science.

Randall, T. \& Baetz, B. (2001) Evaluating pedestrian connectivity for suburban sustainability, Journal of Urban Planning and Development, 127(1), pp. 1-15.

Rengert, G. and Hakim, S. (1998) Burglary in affluent communities: a planning perspective, in Felson, M. and Pieser, R (Eds.). Reducing Crime through Real Estate Development and Management., Washington DC: Urban Land Institute, pp. 39-52.

Rengert, G. and Wasilchick, J. (2000) Suburban crime: a tale of two suburbs. 2nd Edition. Springfield, IL: Charles C. Thomas.

Rubenstein, H., Murray, C., Motoyama, T. and Rouse, W. (1980), The Link between crime and the built environment: the current state of knowledge., Washington DC: National Institute of Justice.

Rudlin, D., \& Falk, N. (1995) 21st Century homes: building to last: a report for the Joseph Rowntree Foundation. London: Urban and Economic Development Group.

Saelens B., Sallis J., Black J. \& Chen D. (2003) Neighborhood-based differences in physical activity: an environment scale evaluation, American Journal of Public Health, 93, pp. 15521558. 
Sanoff, H. \& Dickerson, J. (1971) Mapping children's behavior in a residential setting, Journal of Architectural Education, 25(4), pp. 98-103.

Schneider, R. and Kitchen, T. (2002) Planning For Crime Prevention: A Transatlantic

Perspective. London: Routledge.

Schneider, R. \& Kitchen, T. (2007) Crime Prevention and the Built Environment. London:

Routledge.

Sheard. M. (1991). Report on burglary patterns: the impact of cul-de- sacs. Delta, British Columbia: Delta Police Department.

Shriver, K. (1996) Influence of environmental design in pedestrian travel behaviour in four Austin neighbourhoods, Transportation Research Record, 1578, pp. 64-75.

Shu, S., Huang, J. (2003) Spatial configuration and vulnerability of residential burglary: a Case study of a city in Taiwan, in J. Hanson (Ed.), Proceedings, 4th International Space Syntax Symposium, London.

Smith, B. (1973) Cul-de-sac means safety privacy for home buyer. The Atlanta Journal and Constitution, Section H (January 14), pp. 1-18.

Sorensen D 2003. The nature and prevention of residential burglary: a review of the international literature with an eye towards prevention in Denmark. Available at http://www.jur.ku.dk/medarbejdere/davesorensen/Publikationer/Nature.pdf. Accessed 19 July 2004.

Southworth, M. \& Ben-Joseph, E. (2003) Streets and the shaping of towns and cities. Washington DC: Island Press.

Southworth, M. \& Ben-Joseph, E. (2004) Reconsidering the cul-de-sac. Access, 24, pp. 28-33.

Taylor, R.B. and Gottfredson, S. (1987) Environmental design, crime, and prevention: an examination of community dynamics, in A. J. Reiss \& M. Tonry (Eds.), Communities and crime (Crime and justice: An Annual review of research) 8, pp. 387-416). Chicago: University of Chicago Press.

Town, S. \& O’Toole, R. (2005) Crime-friendly neighborhoods: how new urbanist planners sacrifice safety in the name of openness and accessibility. Available at http://www.reason.com/news/show/36489.html. Accessed 24 January 2007.

Town, S., Davey, C. \& Wooton, A. (2003) Design against crime: secure urban environments by design. Salford: The University of Salford.

UN Habitat (2007) Making cities safer from crime: the safer cities programme. UN-Habitat. Activities Brief. Available at http://www.unhabitat.org/safercities.html. Accessed 23rd April 2008.

UNCHS (1996) The habitat agenda. Available at http://hsd.ait.ac.th/search/search.html. Accessed 23rd April 2008.

United Nations Conference on Environment and Development (1992) Agenda 21. Rio de Janeiro, Brazil: UNCED.

Wagner, A. (1997) A study of traffic pattern modifications in an urban crime prevention program, Journal of Criminal Justice, 25(1), pp. 19-30.

Wells, M. (1993) Neo-Traditional neighborhood development: you can go home again Arlington: Virginia Wells \& Assoc., Inc.

Western Australian Planning Commission (WAPC) (2003) Planning bulletin No. 57 (PB57) 
closure of pedestrian access ways - planning considerations. Perth, WA: The Western Australian Planning Commission.

Western Australian Planning Commission (WAPC) (2009). Reducing Crime and Anti-Social Behaviour in Pedestrian Access Ways. Perth Western Australia: WAPC. Online at: http://www.planning.wa.gov.au/Plans+and+policies/Publications/1882.aspx. Accessed, May 25th 2009.

White, G. (1990) Neighborhood permeability and burglary rates, Justice Quarterly, 7(1), pp. 57-67.

White, R. E. (2004). Police and community responses to youth gangs.Trends \& Issues in Crime and Criminal Justice No. 274. Canberra: Australian Institute of Criminology.

Wiles, P. and Costello, A. (2000) The road to nowhere: the evidence for travelling criminals. Home Office Research Study 207. London, Home Office.

Zavoski, R., Lapidus, G., Lerer, T., Burke, G. and Banco, L. (1999) Evaluating the impact of a street barrier on urban crime. Injury Prevention. 5, pp65-68. 